\title{
Análise semiótica de "Desencanto", de Manuel Bandeira
}

\author{
Dayane Celestino de ALMEIDA (USP / PIBIC-CNPq)
}

RESUMO: Ao longo de sua carreira, Manuel Bandeira escreveu vários poemas que podem ser considerados "poéticas", ou seja, eles tratam do "fazer poesia", ora dizendo para quê a poesia serve, ora dizendo como ela deve ser. Este trabalho apresenta uma análise de um desses poemas - "Desencanto" - sob a perspectiva da semiótica francesa. Especial atenção foi dada à organização do plano da expressão, à aspectualidade e à tensividade no poema.

PALAVRAS-CHAVE: semiótica; aspectualidade; tensividade; poesia; M. Bandeira

\begin{abstract}
Throughout his career, Manuel Bandeira wrote some poems that talk about "making poetry", saying either what the poetry is for or how it should be. This paper presents an analysis of one of these poems - "Desencanto" - from the French semiotics point of view. A special attention was given to the organization of the expression plan, the aspectualization and the tensiveness.
\end{abstract}

KEYWORDS: semiotics; aspectualization; tensiveness; poetry; M. Bandeira 
O livro de estréia de Manuel Bandeira - A Cinza das Horas (1917) - é repleto de poemas de um lirismo melancólico e que remetem a temas como a espera da morte, a frustração, a resignação de quem espera o fim, o sofrimento, a angústia, a tristeza, etc. $\mathrm{O}$ poema que estudamos neste momento foi publicado em tal livro e não é diferente. "Desencanto" é um metapoema que descreve o ato de fazer poesia como uma espécie de "válvula de escape", como um desabafo de um ser que sofre e espera a morte. Assim, ele pode ser considerado uma primeira "poética" de Manuel Bandeira, que descreve para quê a poesia serve. Nossa análise tem por objetivo explicitar como esta relação da poesia com o sofrimento está constituída neste texto e demonstrar os recursos utilizados na construção do sentido. Para tanto, iniciaremos por uma descrição do plano da expressão, averiguando, sempre que possível sua relação com o plano do conteúdo. Num segundo momento, voltaremos nossa atenção especificamente ao plano do conteúdo.

O poema é dividido em três quadras. A primeira pode ser vista como a apresentação do tema, a segunda como sua descrição e a última é a conclusão. Todas as estrofes são compostas por versos de nove sílabas e com esquema de rimas ABAB. Alguns recursos utilizados na construção do poema nos permitem enxergar uma estruturação do plano da expressão. Uma das primeiras coisas que nos chama a atenção quanto a isto, é a maneira pela qual as rimas são compostas. Tanto na primeira quanto na terceira estrofe, há rimas das duas últimas vogais. Observando mais atentamente estas vogais, vemos que tanto as da primeira quanto as da terceira estrofe apresentam regularidades no que diz respeito aos traços [+ - posterior] e [+ - arredondado]. Vejamos o quadro abaixo:

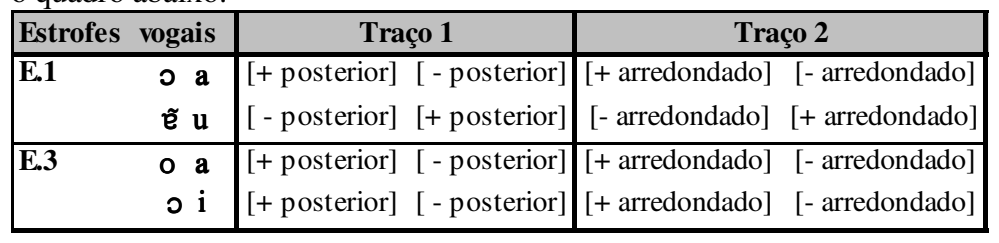

$\mathrm{Na}$ primeira estrofe, há uma construção em quiasmo, ou seja, há uma alternância entre traços "positivos" e "negativos". Já a terceira estrofe apresenta uma construção em paralelo, ou seja, tanto A quanto B começam pelos traços "positivos" e terminam pelos "negativos". Quanto aos traços acima mencionados, vale a pena ressaltar que a oposição posterioridade versus anterioridade é uma oposição qualitativa, conforme Jakobson apud Zilberberg (s/d:54), ou seja, são duas características ou qualidades polares da mesma categoria. Por outro lado, a oposição arredondado versus não-arredondado é privativa, uma vez que ocorre a presença ou ausência de uma certa característica.

Passando para a estrofe 2, verificamos que a rima em A é dada por toda a seqüência fônica -ente ( [ẽjtSI]; em ardente e quente ) e a $\mathrm{B}$ pelo ditongo nasal [̃̃w] (vão, coração). Podemos observar, portanto a evidência das vogais nasais (ditongos nasais) nesta segunda estrofe. Quanto às consoantes que compõe a rima, a 
última consoante é igual para cada par de versos, menos nos versos pares da segunda estrofe, conforme o esquema abaixo:

\begin{tabular}{|c|c|c|}
\hline Estrofe 1 & Estrofe 2 & Estrofe 3 \\
\hline v. 1 e $3[\Gamma]$ & $\mathrm{v} .1$ e 3 [t $\left.\int\right]$ & v. 1 e $3[\mathrm{k}]$ \\
\hline v. 2 e $4 \quad[t]$ & v. $2 \quad[\mathrm{v}]$ & v. 2 e $4[\mathrm{X}]$ \\
\hline
\end{tabular}

$\mathrm{Na}$ terceira estrofe, observamos um quiasmo das consoantes $[\mathrm{X}]$ e $[\mathrm{k}] \mathrm{em}$ rouca e corre:

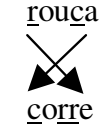

$\mathrm{Na}$ estrofe 1, as consoantes mencionadas têm em comum o seu ponto de articulação: tanto [ $\Gamma$ ] quanto [t] são consoantes alveolares. A mesma correspondência de ponto de articulação ocorre na estrofe 3: ambas as consoantes ( $[\mathrm{k}]$ e $[\mathrm{X}]$ ) são velares. Assim, vemos que houve uma simetria com relação aos sons que compõem as rimas das estrofes 1 e 3 , evidenciada pelo que acabamos de verificar e pelo que mencionamos anteriormente acerca dos traços das vogais. Além disso, ressaltamos que é na estrofe 2 que ocorre a única rima "masculina", ou seja, é a única vez em que rimam palavras oxítonas (vão e coração) em todo o poema. Tal fato, juntamente com as relações percebidas entre as estrofes 1 e 3, parece apontar para uma singularidade da segunda estrofe, com relação às demais. Há mais relações entre as estrofes 1 e 3 do que entre qualquer uma dessas e a 2 , como fica claro nesta exposição. As afinidades entre a primeira e a terceira estrofe e a singularidade da segunda podem ser vistas não só no plano da expressão, mas também no plano do conteúdo. Como já dissemos anteriormente, a estrofe 1 apresenta o tema e a 3 é a conclusão. Elas apresentam, pois, a abertura e o fechamento do poema. O primeiro verso da estrofe 1 (portanto, o verso que abre o poema) é Eu faço versos como quem chora, paralelo ao verso Eu faço versos como quem morre, que é justamente o último da estrofe 3 (ou seja, o verso final). Por sua vez, a estrofe 2, sendo a do meio, corresponde exatamente ao desenvolvimento do tema proposto. Ora, apresentação ou introdução e conclusão sempre estão muito ligados nos textos em geral.

Quanto à sonoridade destas últimas consoantes, vemos que as estrofes 1 e 2 apresentam um misto entre consoantes surdas e sonoras, enquanto que a terceira estrofe apresenta apenas surdas. Quando olhamos para o início de cada verso, vemos que o primeiro som nas estrofes 1 e 2 são ou surdos ou sonoros e que na terceira estrofe, (ao contrário do que ocorreu na rima), todos os sons são sonoros.

Mais uma semelhança entre a primeira e a terceira estrofe no que diz respeito às rimas pode ser vista quando reparamos nas classes de palavras que as compõem. Na estrofe 1, a mesma classe de palavras (substantivos) é utilizada nos versos pares. E os versos pares da terceira estrofe também repetem o mesmo tipo de palavras (desta vez, verbos). Na estrofe do meio, por outro lado, há repetição da mesma classe de palavras nos versos ímpares. 
Outras observações com relação à matéria fônica são pertinentes e revelam a organização do plano de expressão. Na estrofe 1, destaca-se a grande quantidade de fricativas no verso 1: Eu faço versos como quem chora e a grande ocorrência de nasais (tanto vogais quanto consoantes no verso 4: Não tens motivo nenhum de pranto.

Ainda na estrofe 1, notamos uma relação simétrica entre a quantidade de consoantes surdas e sonoras e o local onde elas aparecem. Os versos 1 e 4 apresentam mais surdas que sonoras, ao passo que os versos 2 e 3 ("encapsulados" pelos outros dois) apresentam mais sonoras do que surdas. Vejamos o quadro abaixo que representa bem tal simetria.

\begin{tabular}{|c|c|c|c|}
\hline Qtd de consoantes: & V 1 & V $3 \quad$ V 4 & Total \\
\hline Surdas & 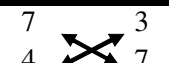 & $4 \times$ & 21 \\
\hline \begin{tabular}{|l} 
Sonoras \\
Total
\end{tabular} & $\begin{array}{rr}4 & \mathbf{1} \\
11 & 10\end{array}$ & $\frac{7}{11}$ & $\frac{22}{43}$ \\
\hline
\end{tabular}

Semanticamente, os versos 1 e 4 também se relacionam: eles apresentam as palavras chora e pranto, respectivamente.

Passando à estrofe 2, notamos que a distribuição entre surdas e sonoras é a seguinte: v1: predominância das sonoras; v2: predominância das surdas; v3: predominância das sonoras; v4: predominância das surdas. Percebe-se, portanto uma alternância entre estas consoantes, diferentemente do que ocorreu na estrofe 1, onde havia relação entre os dois versos centrais versus os dois marginais. Além de terem afinidades no que diz respeito ao traço [+ sonoro] das consoantes, os versos 1 e 3 podem ser cotejados também semanticamente: sangue - veia; ardente - quente. $\mathrm{O}$ mesmo ocorre com os versos 2 e 4 por estarem relacionados às noções de extensidade e intensidade (verso 2, extensidade: tristeza esparsa; verso 4, intensidade: cai gota a gota).

Ainda com relação à organização do plano sonoro, outros pontos verificados foram: a) verso 2: assonância: [s], conforme destacado em negrito: "Tristeza esparsa... remorso vão..."; b) verso 4: neste verso, há a expressão, "Cai gota a gota", que apresenta uma seqüência de consoantes oclusivas, conforme destacado em negrito. A presença destas oclusivas, juntamente com o ritmo, ajuda a realçar a imagem e o som de gotas caindo.

Particularidades no que tange a sonoridade foram também percebidas na terceira estrofe. Nesta, o som [s] é muito recorrente. Do total de consoantes desta quadra, $26 \%$ são [s], contra apenas $9 \%$ na primeira estrofe e $18 \%$ na segunda. Do total de todos os [s] do poema, $50 \%$ estão na terceira estrofe. Esta consoante fricativa remete a algo que corre, desliza e pode ser, assim, associada à vida que se esvai (a vida corre).

Quanto ao ritmo, este é bem marcado e regular em todo o poema, com o acento sempre na quarta e na nona sílaba. Se os versos fossem divididos ao meio, veríamos que

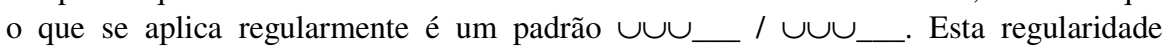
rítmica corresponde a grupos de palavras dentro de alguns versos, que formam uma unidade, como por exemplo, uma sentença ou um sintagma. No verso 1, por exemplo, a cesura ocorre exatamente onde se separa a oração principal da oração subordinada. No 
verso 2, separa os sintagmas preposicionais "de desalento" e "de desencanto". No verso 5, a cesura ocorre justamente com o ponto final, encerrando a oração Meu verso é sangue. Em seguida, o mesmo padrão rítmico é percebido na série, volúpia ardente, tristeza esparsa, remorso vão. Nos dois versos que seguem, o corte também acompanha a pontuação.

Uma vez terminado o exame do plano da expressão, passamos, agora, à análise do plano do conteúdo. Do ponto de vista narrativo, o texto não apresenta uma transformação. O que encontramos é a apenas a descrição de um estado do sujeito que está em disjunção com o objeto de valor. Esta ausência do programa narrativo completo é comum em textos descritivos (que é o caso deste poema, que descreve a poesia) como diz Fiorin (2005:46):

"Uma das características do texto descritivo poderia ser a manifestação de apenas um dos estados do nível narrativo (o inicial ou o final) e não da transformação completa (passagem de um estado a outro)...".

Desde o título, já é possível depreender este estado do sujeito, uma vez que desencanto, de acordo com o dicionário Houaiss, significa "estado daquele que se decepcionou, que perdeu as ilusões". Diante de tal definição, podemos repensar o estado juntivo do sujeito e dizer que ele está em não-conjunção com o objeto de valor, uma vez que ele perdeu, as ilusões. Desta forma, consideramos que o estado passional do sujeito é o da insatisfação, uma vez que, em termos modais, ele quer-ser, não-crê-ser e sabe-não-poder-ser em conjunção com o objeto e, em termos juntivos, seu estado é o da não-conjunção com o objeto esperança ou ilusões. Em contrapartida, está em conjunção com o sofrimento causado pela espera da morte, conjunção esta não desejada. A falta vivida pelo sujeito pode se resolver de duas maneiras, conforme Barros (2003:51): "pela reparação ou pela resignação e conformação". No texto em questão, é a segunda opção que vigora, uma vez que o sujeito faz versos de desalento (que significa, segundo o dicionário Houaiss, "estado de quem se mostra sem ânimo, desânimo, abatimento") e, na terceira estrofe, vemos um sujeito conformado diante da idéia de que não mais conseguirá sair daquela situação, como indicado pelo verso Assim dos lábios a vida corre, em que a conjunção Assim indica essa noção de conformidade, intensificada pelo verso final - Eu faço versos como quem morre, que mostra que o sujeito está tão resignado que apenas espera a morte. Resumindo, percebemos a existência de um sujeito insatisfeito, triste e resignado. É este estado de desencanto, mágoa e resignação do sujeito do enunciado que serve de matéria para o sujeito da enunciação compor o poema.

Como esse sujeito não quer fazer nada, está resignado e apenas espera a morte, vemos que há uma aspectualização do seu comportamento. Esse sujeito "vive" esperando o fim (destaque pro ultimo verso: Eu faço versos como quem morre; espécie de resumo do que ele falou antes e também a conclusão do poema). Portanto, podemos dizer que esse comportamento do sujeito tem um aspecto terminativo. A terminatividade é encontrada muitas vezes ao longo do poema. Por exemplo, no próprio último verso, que já citamos, encontra-se a palavra morre, portadora de um aspecto terminativo. Outros elementos do poema que remetem a um aspecto terminativo são: 
1) desencanto (é o estado de quem perdeu as ilusões, ou seja, sem ilusões);

2) A expressão fecha meu livro.

3) Meu verso é sangue (figura do sangue associada à morte).

4) Os adjetivos ardente e quente que correspondem a uma sensação de queimar, de algo queimando. De acordo com o dicionário Houaiss, queimar é "destruir pelo fogo, fazer em cinzas", então novamente aspecto terminativo.

5) A expressão a vida corre. Aqui, o verbo correr considerado sozinho portaria um aspecto durativo, mas, junto de vida, na expressão $a$ vida corre, que significa a vida se esvai, a vida que acaba, o aspecto é terminativo.

6) A expressão cai gota a gota tem o verbo cair, com aspecto terminativo. Já gota a gota poderia ser associada à duratividade. Porém, no contexto do poema essa expressão ajuda a reforçar a idéia de que a morte vai chegar paulatinamente, devagar. Desta forma, podemos considerar a expressão cai gota a gota como portadora de um aspecto terminativo e dizer que esta terminatividade ocorre num andamento lento. Quanto a este andamento lento, o mesmo acontece em a vida corre, que, no poema, é seguida por deixando (a vida corre deixando um acre sabor...). O gerúndio deixando também indica um andamento lento da terminatividade dada por a vida corre (corre, neste contexto, perde seu traço de "rapidez").

Voltando um pouco ao ponto em que falamos sobre o sujeito estar insatisfeito, magoado e resignado, gostaríamos de citar uma passagem de Barros (2001:65):

"A insatisfação e a decepção podem ser determinadas aspectualmente pela duração e prolongar-se em novos efeitos passionais: a mágoa que perdura ou a resignação, por exemplo".

Essa afirmação é interessante, para que possamos ver que a mágoa e resignação do sujeito em "Desencanto" são determinadas aspectualmente. Acreditamos que isto vai ao encontro daquilo que acabamos de falar sobre o andamento lento. Foi essa demora, essa duração lenta ou andamento lento que intensificaram o sofrimento do sujeito, porque ele está "desencantado", perdeu as ilusões, a esperança, sabe que vai morrer, mas a morte não vem rápido. Ele vive na iminência da morte e aquela demora é que gera a tristeza e a resignação. Fazendo uma ponte com o nível discursivo, podemos verificar esta tristeza do sujeito figurativizada por pranto, tristeza esparsa, remorso vão, sangue, dói-me, amargo, acre. Tudo isto culmina na angústia rouca descrita no poema.

A partir das considerações já feitas, podemos depreender que, no nível fundamental, a categoria semântica básica que opera é Vida versus Morte. A julgar pelo comportamento terminativo do sujeito, que vive na iminência do fim e nada faz para reverter a situação e no prolongamento do seu estado (de sofrimento, tristeza, resignação), podemos dizer que ele vai negando a Vida e afirmando a Morte, o que pode também ser corroborado pelo verso final (Eu faço versos como quem morre). Em termos tensivos, observamos que há uma continuação da parada, ou seja, há uma continuidade do estado do sujeito que nada faz, está resignado. Lembremo-nos de que a resignação foi o estado gerado pela prolongação do estado anterior (insatisfação). Tais relações podem ser melhor visualizadas graficamente a partir do seguinte quadrado semiótico: 


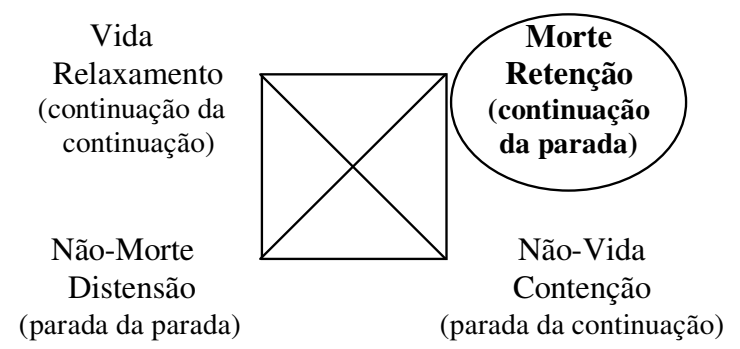

No que diz respeito à semântica discursiva, "Desencanto" apresenta o tema do "fazer poesia". Figuras como versos (reiterada várias vezes ao longo do poema) e livro compõem o percurso figurativo do "fazer poético". Mais especificamente, porém, podemos dizer que o tema é o do "fazer poético, como fuga do sofrimento". Conforme já mencionamos no início deste trabalho, "Desencanto" diz para quê a poesia serve: como um desabafo, uma "válvula de escape". Assim, há figuras que nos permitem identificar uma isotopia do sofrimento: pranto, desalento, desencanto, sangue, angústia, acre, remorso, entre outras que melhor explicitaremos a partir de agora.

Quando da análise do nível narrativo, mencionamos que "Desencanto" pode ser considerado um texto descritivo, pois há apenas a descrição de um estado. Através da descrição de tal estado é que a poesia é, indiretamente, descrita. Na primeira estrofe, não encontramos adjetivos. No entanto, ela não deixa de ser descritiva, pois esta característica é mantida pela conjunção como, estabelecendo uma comparação, na proposição Eu faço versos como quem chora de desalento de desencanto. A segunda estrofe é a mais descritiva das três. Ela vai descrever o verso, o ato de compor relacionado ao sofrer. Nela aparecem os adjetivos pela primeira vez e em maior quantidade: dos sete adjetivos presentes no poema, cinco estão aqui. Vejamos, portanto, como se relacionam os substantivos e adjetivos (e também palavras de outras classes) nas três estrofes. Regularidade e simetria na construção podem ser observadas na primeira delas. Com relação aos substantivos, dos seis que compõem esta estrofe, três são concretos (versos, livro e pranto) e três são abstratos (desalento, desencanto e motivo), três exercem a função sintática de adjunto (desalento, desencanto, pranto) e três de complemento (versos, livro, motivo); os versos ímpares têm um substantivo cada e os pares, dois substantivos cada. Os substantivos dos versos ímpares estão relacionados tanto semanticamente como foneticamente: versos - livro (repetição de [v], [r] e [u]). Eles evidenciam, logo de início, o caráter metalingüístico deste texto. Os substantivos dos versos pares também se relacionam semântica e foneticamente: desalento - desencanto - pranto. Todos eles ligados ao sofrer. Reparamos na repetição do prefixo - des e dos três sons iniciais destas palavras. Consideremos também que desencanto rima como pranto, intensificando a relação entre eles. Apenas o substantivo motivo dos versos pares não está relacionado semântica ou foneticamente, mas está sintaticamente, pois é o núcleo da expressão "motivo nenhum de pranto". Motivo 
relaciona-se também com livro foneticamente. Ambos apresentam os sons [i], [v] e [u], na mesma seqüência e nas mesmas sílabas (quarta: [i], quinta: [v] e [u]) dos seus respectivos versos. Esta dupla relação de motivo tanto com os substantivos dos versos pares quanto com os de versos ímpares reforça a idéia de que o desencanto, o desalento e o pranto é que são o motivo para os versos e o livro. Nesta estrofe, portanto, apresenta-se o tema principal do poema.

Na segunda estrofe, os primeiros substantivos são verso e sangue. Verificamos então a metáfora $M e u$ verso é sangue, na qual, apesar de não ser adjetivo, sangue está exercendo a função de predicativo do sujeito e, portanto, qualifica verso, novamente evidenciando o ato descritivo. Assim como na primeira estrofe, aqui também vemos muita regularidade na composição e distribuição dos substantivos. Dos setes substantivos presentes, há quatro concretos que são exatamente os dois primeiros e os dois últimos da estrofe. Três deles estão relacionados: sangue, veias, coração. O verso que faz doer as veias e que cai gota a gota do coração, na verdade "cai" do sujeito como um todo e faz doer não só as veias como o ser inteiro. Veias e coração são, então, uma metonímia de corpo (há uma relação da parte pelo todo). Os três substantivos abstratos são os do meio e se relacionam: remorso (arrependimento) se relaciona com tristeza e ambos, junto com o verbo doer ("dói-me" nas veias) reiteram o sofrimento de quem compõe os versos. Estes três abstratos são também os três que recebem adjetivos (volúpia ardente, tristeza esparsa, remorso vão) e, assim como sangue, têm a função sintática de predicativo do sujeito, qualificando verso. Esta adjetivação é reforçada pela sequiência em que aparecem os sintagmas adjetivais citados acima, bem como pela sua semelhança; os pares volúpia ardente, tristeza esparsa, remorso vão, formam uma série, na medida em que são apresentados em seqüência e compostos da mesma forma (nome + adjetivo). Esta série também evidencia o jogo que há, em toda a segunda estrofe, entre os conceitos semióticos de intensidade e extensidade. Segundo Lopes (2005:206):

"A extensidade mostra-se na tensão contínua entre o uno e o múltiplo (...). Quanto à intensidade, o que varia é a medida, seja da tonicidade - numa linha que vai do átono ao tônico -, seja do andamento - num contínuo que vai do mais lento ao mais rápido”.

Desta forma, verificamos que o sintagma adjetival volúpia ardente corresponde a um mais no eixo da intensidade, uma vez que volúpia, segundo o dicionário Houaiss, significa "grande prazer dos sentidos", ou seja, há uma maior tonicidade, reforçada pelo adjetivo ardente que - numa escala de sensações térmicas, que vai do gelado, passando pelo frio, fresco, morno - se encontra depois do quente. Portanto, ardente também evidencia um mais no eixo da intensidade, conforme corrobora a sua definição no dicionário (segundo o Houaiss): "1. que queima em chamas ou brasas, 2. que concentra ou causa calor, 3. picante, 4. entusiasmada, intenso". Destaque para as palavras "concentra" e "intenso". Esta gradação do gelado ao ardente pode ser representada, graficamente, da seguinte forma:

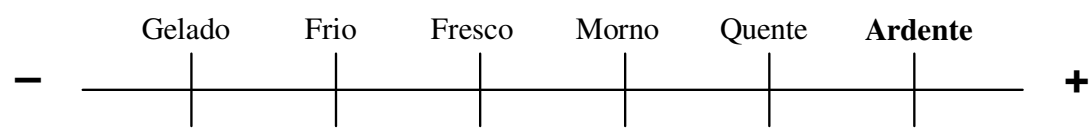


Na sequiência, tristeza esparsa é uma expressão considerada da ordem da extensidade. O adjetivo esparso, segundo o dicionário Aurélio, significa "disperso", "espalhado", o que corresponde_a_um mais_no_eixo_da_extensidade. Até o momento, o que se pode ver é uma correlação chamada direta ou conversa entre intensidade e extensidade, ou seja, a um mais em um desses eixos, corresponde também um mais no outro. O último sintagma da série - remorso vão - pode ser concebido como da ordem da intensidade. Uma acepção para o adjetivo vão é, segundo o dicionário Houaiss, algo que "não tem eficácia, inútil". Desta forma, este adjetivo intensifica o sentido do nome que modifica - remorso -, uma vez que remorso é uma "inquietação da consciência que percebe ter cometido erro; arrependimento" (dicionário Houaiss). O remorso já é, por si só, um sentimento que incomoda, que é doloroso; pior ainda deve ser um remorso inútil. Outra observação importante acerca desta expressão, é que um remorso vão é algo que não desencadeia um novo fazer, o que vai ao encontro do que dissemos anteriormente sobre o sujeito do enunciado estar conformado, sem ânimo, sem vontade, o que resulta na ausência da função narrativa.

Ainda quanto à noção de intensidade versus extensidade na segunda estrofe, podemos considerar os vocábulos coração e veias (Dói-me nas veias. Amargo e quente, / Cai, gota a gota, do coração.), pois o coração é o órgão que concentra o sague, enquanto as veias são responsáveis pela sua distribuição ou expansão. Podemos, portando, falar em concentrado e expandido, onde concentrado corresponde a uma mais no eixo da intensidade e expandido, por se tratar do espaço, a um mais no eixo da extensidade, isto é, mais uma vez, o que se tem é uma correlação conversa, que pode ser representada (assim como a anterior) pela seguinte figura:

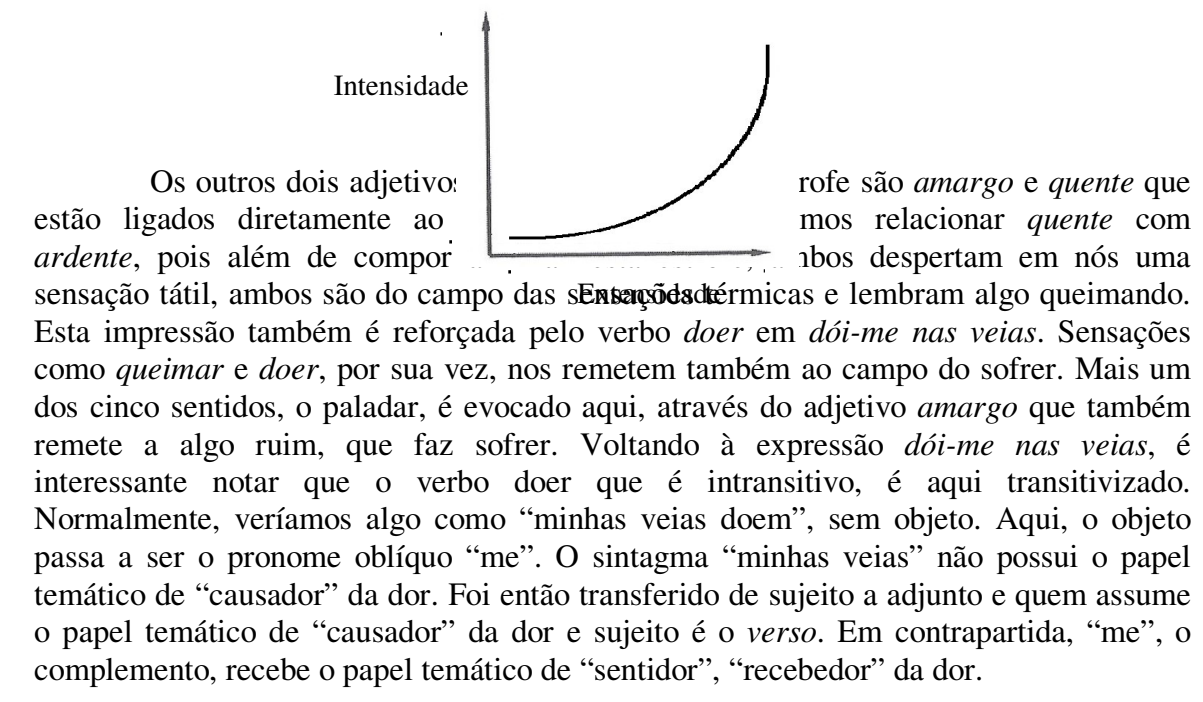

www.fflch.usp.br/dl/semiotica/es 
Passando para a última estrofe, verificamos que nela realmente há uma conclusão, salientada pelas conjunções $E$ (E nestes versos de angústia rouca) e Assim (Assim dos lábios a vida corre). O sujeito conclui que realmente sofre (figuras ligadas ao sofrimento continuam aparecendo: angústia rouca, acre sabor) e que a sua poesia é um desabafo de alguém que morre. Portanto, o texto é finalizado reiterando tudo o que havia sido dito nas estrofes anteriores e, diante de todo o sofrimento, o sujeito conclui, conformado, que o único fim só pode ser a morte (-Eu faço versos como quem morre). Voltando ao primeiro verso desta quadra, observamos a expressão angústia rouca. Nela percebemos que rouca é uma característica humana: a voz humana pode ficar rouca. Porém, no texto, rouca qualifica um sentimento: a angústia, que, ao receber este traço humano fica personificada. Esta transferência de algo que se relaciona geralmente a algo animado, humano para um sentimento põe tal sentimento em evidência, dando força a ele no contexto. $\mathrm{O}$ adjetivo rouca também significa que alguém não pode falar normalmente e isto, de certa forma, angustia. Portanto, se a angústia já é por si só algo que atormenta, inquieta, imagine-se uma angústia rouca. E rouca forma, junto com lábios (verso 2) e sabor e boca (verso 3) uma isotopia. Uma metonímia pode ser verificada mais uma vez aqui, ao passo que lábios e boca também representam corpo ou, mas amplamente falando, vida.

Este jogo entre concreto e abstrato perpassa todo o poema. Por exemplo, no verso Assim dos lábios a vida corre, vida ganha um traço corporal, pois dos lábios não corre vida. Este vocábulo passa então de abstrato a concreto, ao contrário do que ocorre com o vocábulo verso na segunda estrofe, que passa de concreto a abstrato ao juntar-se aos adjetivos amargo e quente e às expressões tristeza esparsa e remorso vão. Vemos ainda a utilização de figuras que transitam entre o físico e o metafísico, ou seja, uma aproximação entre "corpo" e "alma", por exemplo, em coração, que pode ser mencionado tanto como órgão do corpo físico, quanto como manifestação abstrata, relacionado ao sentimento, à "alma". O mesmo ocorre com sangue e vida, que podem ter conotações abstratas ou concretas, relacionadas ao corpo ou à alma.

Também na terceira estrofe, notamos que o primeiro e o segundo verso integram uma única proposição que está apresentada no poema em ordem inversa. Sua ordem "normal" seria "A vida corre dos lábios nestes versos de angústia rouca", onde vemos mais claramente que os versos são instrumento de expressão da vida que se esvai: "nestes versos" equivale a "através destes versos". O verbo corre lembra também "escorre" e aqui podemos fazer uma relação com a vida que corre/escorre com o verso/sangue da estrofe anterior que também corre e "dói" nas veias. Portanto, a vida corre (escorre) desperta também uma sensação tátil. No verso seguinte, acre sabor desperta um outro sentido: o paladar que havia sido despertado na estrofe 2 pelo adjetivo amargo da estrofe anterior.

A conclusão de que o verso é morte ou expressão de quem espera a morte pode também ser corroborada por anagramas no poema. A segunda estrofe, que é justamente a mais descritiva de todo o poema, que qualifica "meu verso", apresenta a palavra morte anagramatizada em três de seus quatro versos:

Meu verso é sangue. Volúpia ardente...

Tristeza esparsa... remorso vão... 
Dói-me nas veias. Amargo e quente,

Cai, gota a gota, do coração.

Daí, podemos concluir que o verso é sangue e é também morte (Meu verso é sangue $=>$ Meu verso é morte). Nas outras duas estrofes, a forma verbal morre também aparece em anagramas. Na estrofe 1, morre aparece em dois versos e morte em um. E na última estrofe, morre aparece em anagramas em dois versos e em sua forma normal no último verso. Lembremos que o poema começa com Eu faço versos como quem

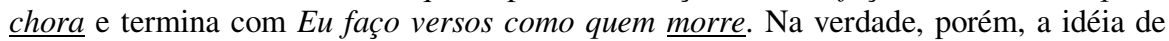
morte já está presente desde o início se interpretarmos que morre em anagrama já antecipa o como quem morre do final. Vejamos os versos:

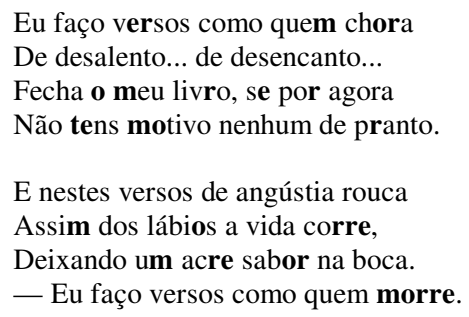

Pelos motivos acima explicitados, acreditamos que os anagramas não estão dispostos por mera coincidência; e também porque há uma simetria na sua distribuição. Em todas as estrofes (de quatro versos), aparece um anagrama (morre ou morte) sempre disseminado em três versos (na última estrofe, a palavra morre aparece anagramatizada em dois versos, mas aparece inteira no último verso).

Quanto à sintaxe discursiva, do ponto de vista da enunciação, o texto começa com um "eu" dirigindo-se a alguém que ocupa o lugar de "tu", a quem comunica o tema da sua poesia e propõe um contrato ao dizer que este deve fechar o livro se não tiver motivo algum de pranto (Cf. versos 3 e 4, estrofe 1). Verificamos aqui que se instaura, portanto, uma relação que envolve os actantes destinador e destinatário. A intenção do enunciador-destinador é fazer o enunciatário-destinatário ler o poema, mas apenas se compartilhar de sua realidade, ou seja, se tiver também motivo de pranto. A existência destas funções é corroborada pela presença de pronomes de primeira pessoa (Eu, meu) do imperativo (Fecha o meu livro...). Vemos que há marcas da enunciação no enunciado $\mathrm{e}$, mais precisamente, que se trata de uma debreagem enunciativa.

No último verso, opera-se, ainda, uma debreagem interna (ou de segundo grau), indicada pelo uso do travessão. O enunciador dá a voz para uma pessoa já enunciada anteriormente no discurso: eu. $\mathrm{O}$ eu da primeira debreagem enunciativa faz uma outra debreagem do mesmo tipo, instaurando novamente um eu. Isso reitera e intensifica a subjetividade do discurso, criando um maior efeito de sentido de verdade. O fato deste último verso ser o único em todo o poema que, sozinho, é uma proposição é mais um fator que singulariza e dá força a ele. É como se este verso sozinho ganhasse força o bastante para sintetizar tudo o que estava sendo dito. E, de fato, ele é um resumo do que o precede. 
Voltando ao tema do poema - a poesia como desabafo, como expressão do sofrimento de quem espera a morte - um recorte intertextual pode nos mostrar que a espera da morte, a frustração, a resignação de quem espera o fim, etc, eram assuntos constantes na obra de Bandeira, principalmente nos primeiros livros, como podemos, por exemplo, ver nos trechos a seguir:

1. A vida é amarga. O amor, um pobre gozo...

Hás de amar e sofrer incompreendido,

Triste lírio franzino, inquieto, ansioso,

Frágil e dolorido... ${ }^{1}$

2. E nesse tom sem consolo

Ouço a voz do meu destino.

Má sina que desconheço,

Vem vindo desde eu menino,

Cresce quanto em anos cresço. ${ }^{2}$

3. Sinto que a minha vida é sem fim, sem objeto...

- Ah, como dói viver quando falta a esperança! ${ }^{3}$

Não é objetivo deste trabalho analisar minuciosamente os trechos supracitados. Porém, consideramos válido examiná-los de forma breve. No primeiro trecho transcrito, uma isotopia do sofrimento é formada por: vida amarga, sofrer, incompreendido, triste, franzino, inquieto, ansioso, frágil e dolorido. Podemos ver um sujeito decepcionado e num estado passional de amargura e tristeza. Elementos normalmente eufóricos, como vida e amor, aparecem aqui como disfóricos, evidenciando a decepção do sujeito. Vida é modificada pelo adjetivo amarga e o amor, por sua vez, é descrito como um pobre gozo. O fato de o amor ou o ato de amar serem considerados ruins podem ser corroborados também pela relação fonética existente entre amarga e amor (ou amar). Há uma combinação de decepção (a vida é amarga, incompreendido, dolorido) e aflição (inquieto, ansioso). No segundo trecho, verificamos um sujeito "desconsolado", que só vê a sua má sina aumentar. Ao dizer que ouve a voz do destino num tom sem consolo, o sujeito admite estar num estado de resignação. Ele está conformado com os desígnios do destino e com sua má sina. Assim como em "Desencanto", aqui a falta é reparada pela resignação que resulta num esvaziamento modal, ou seja, o sujeito não quer mais fazer nada. Por fim, o sofrimento também aparece no terceiro trecho. $\mathrm{O}$ sujeito apenas espera a morte, uma vez que falta a esperança. Ele também se mostra aflito e resignado ao declarar que sua vida é sem fim e sem objeto. O sujeito aqui é um sujeito em falta, em disjunção com qualquer objeto, o que configura um estado de espera tensa (dói viver quando falta a esperança).

A análise que fizemos de "Desencanto" como uma poética vai ao encontro do que diz o crítico Davi Arrigucci Jr. (2003:132-133) quando afirma que a poesia de Bandeira é:

"uma experiência da ameaça de morte. Esta que é uma condição geral de toda existência humana, se fez, no seu caso, um risco próximo e permanente (...). O rapaz que só fazia versos por divertimento ou brincadeira, de repente, diante do ócio obrigatório, do 
sentimento de vazio e tédio, começa a fazê-los por necessidade, por fatalidade, em resposta à circunstância terrível e inevitável (...). Nascendo junto com a circunstância adversa, a poesia é então percebida como um desabafo momentâneo (...)”.

\section{REFERÊNCIAS BIBLIOGRÁFICAS:}

ARRIGUCCI Jr., Davi. Humildade, paixão e morte: a poesia de Manuel Bandeira. São Paulo: Cia. das Letras, 1990.

BANDEIRA, Manuel. Estrela da vida inteira. Rio de Janeiro: Nova Fronteira, 1993.

BARROS, Diana Luz Pessoa de. Teoria do discurso: fundamentos semióticos. São Paulo: Humanitas, 2001.

BERTRAND, Denis. Caminhos da semiótica literária. Trad. Grupo CASA. Bauru: EDUSC, 2003.

FIORIN, José Luiz. Elementos de análise do discurso. São Paulo: Contexto, 2005.

GREIMAS, Algirdas Julien; COURTÉS, Joseph. Dicionário de semiótica. São Paulo: Cultrix, 1983 .

. Sémiotique: dictionnaire raisonné de la théorie du langage-II. Paris: Hachette, 1986.

JAKOBSON, Roman. Lingüística. Poética. Cinema. São Paulo: Perspectiva, 2004. . Poética em ação. São Paulo: Perspectiva, 1990.

LOPES, Ivã Carlos; HERNANDES, Nilton (orgs.). Semiótica: objetos e práticas. São Paulo: Contexto, 2005.

TATIT, Luiz. Análise semiótica através das letras. São Paulo: Ateliê Editorial, 2001.

ZILBERBERG, Claude. Razão e poética do sentido. No prelo. 


\section{ANEXOS}

\section{DESENCANTO}

Eu faço versos como quem chora

De desalento... de desencanto...

Fecha o meu livro, se por agora

Não tens motivo nenhum de pranto.

Meu verso é sangue. Volúpia ardente...

Tristeza esparsa... remorso vão...

Dói-me nas veias. Amargo e quente,

Cai, gota a gota, do coração.

E nestes versos de angústia rouca

Assim dos lábios a vida corre,

Deixando um acre sabor na boca.

— Eu faço versos como quem morre.

Teresópolis, 1912

\section{Como citar este artigo:}

ALMEIDA, Dayane Celestino de. Análise semiótica de "Desencanto", de Manuel Bandeira. Estudos Semióticos, Número 3, São Paulo, 2007.

Disponível em <www.fflch.usp.br/dl/semiotica/es $>$. Acesso em "dia/mês/ano".

${ }^{1}$ Do poema Imagem (In: A Cinza das Horas, 1917).

${ }^{2}$ Do poema Oceano (In: A Cinza das Horas, 1917).

${ }^{3}$ Do poema Desesperança (In: A Cinza das Horas, 1917). 